\title{
Resenha
}

\section{A leitura atravessa os umbrais}

Glória Kok, pós-doutora do Departamento de Antropologia da Unicamp, pesquisadora do Centro de Pesquisa em Etnologia Indígena e professora do ISE Vera Cruz

Examinar os múltiplos sentidos da leitura para os jovens que vivem nos bairros marginalizados franceses foi o principal desafio da antropóloga Michèle Petit, pesquisadora do Laboratório de Dinâmicas Sociais e Recomposição dos Espaços e do Centre National de la Recherche Scientifique, na França. Como resultado, a autora organizou quatro conferências aqui reunidas que trazem uma reflexão sensível e luminosa sobre o exercício da leitura, bem como as trajetórias de alguns jovens leitores e suas aventuras pelo mundo dos livros. Nesse itinerário, sublinha a importância das bibliotecas públicas, dos professores, das bibliotecárias e dos educadores na formação do leitor e na luta contra a exclusão. Para ela, "a leitura tem o poder de despertar em nós regiões que estavam até então adormecidas" (p. 7). É justamente esse processo de sensibilização para dimensões oníricas e libertárias vivido na atividade de leitura que articula e permeia todas as conferências.

A primeira delas versa sobre as experiências singulares dos leitores, uma vez que ler, comenta a autora, "permite ao leitor, às vezes, decifrar sua própria experiência" (p. 38). A segunda refere-se, sobretudo, ao papel da leitura na construção de si mesmo, fundamental no período da adolescência e juventude. 0 depoimento do argelino Ridha, de 22 anos, ilustra a vinculação da leitura à construção de sua própria identidade. Diz ele: "Eu tinha um livro que reencontrei aqui [na biblioteca municipal] o que me deu muito prazer. [...] é como encontrar também uma referência. Um caminho, um rastro em um trajeto. Experimentamos uma sensação boa mas, em algum lugar, experimentamos algo mais forte: é ser dono de seu destino" (p. 59). Deste modo, conclui Michèle Petit, "a leitura representava tanto um atalho para elaborar sua subjetividade quanto um meio de chegar ao conhecimento" (p. 20). 
A terceira conferência trata do medo em relação ao livro, que, potencialmente, transporta ao leitor códigos de transformações, de conhecimento da língua, de encontros, de buscas e de enfrentamentos, que, não raro, assustam leitores jovens e adultos. 0 escritor italiano Alessandro Baricco precisa: "A literatura deve ser um meio para que possamos enfrentar a tristeza da realidade, os nossos medos e o silêncio. Ela deve tentar pronunciar palavras, pois temos medo do desconhecido e do inominável" (p. 136).

Por fim, a última conferência se debruça sobre o papel dos mediadores do livro na experiência de leitura dos jovens. Havia uma jovem de origem turca que se manteve na escola graças ao seu professor de matemática e sempre encontrou apoio das bibliotecárias de seu bairro. Na ocasião da pesquisa, estava no último ano do ensino médio e queria ser professora. Havia se tornado uma leitora e já ajudava as crianças de seu bairro a fazer suas lições.

Para muitos jovens, portanto, a leitura ultrapassa umbrais, apresenta caminhos e amplia universos culturais. Na biblioteca, podem explorar o mundo e redesenhar seus próprios horizontes. É o que diz o depoimento de Fethi, um rapaz de dezessete anos: "A biblioteca é uma caixa de ideias, uma caixa de surpresas. Quando era pequeno, cada vez que entrava e depois saía, tinha a sensação de ter descoberto alguma coisa, sentia-me mais velho. Com a leitura nos desenvolvemos, temos um modo de vida diferente dos outros, nos tornamos diferentes. A biblioteca é como a água" (p. 189). E Michèle Petit, com maestria, nos trouxe à fonte.

\section{REFERÊNCIA}

PETIT, Michèle. Os jovens e a leitura. Uma nova perspectiva. Tradução Celina Olga de Souza. São Paulo: Editora 34, 2008.

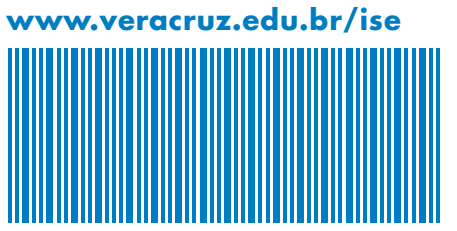

